\title{
Seed Priming Significantly Affects Germination and Post Germination Early Seedling Growth in Okra
}

\section{Rima Rima}

Faculty of Food Science and Nutrition, Poznan University of Life Sciences, Poznan, Poland.

*Corresponding Author Email: asporshi.rema1993@gmail.com

\section{Doi: 10.2478/mjhr-2021-0003}

Abstract: Seed priming significantly affects germination and post germination emergence in seedling of plants. Okra is an important vegetable plays significant role in human nutrition. However, little information is available regarding effect of seed priming on germination and post germination early vegetative growth. Therefore, a pot experiment was conducted to find out the effect of seed priming on the emergence and seedling vigor in different okra varieties. Six local Bangladeshi okra varieties were primed in water for 24 hours and evaluated their germination and post germination emergence. The varieties were named as $\mathrm{V}_{1}-\mathrm{V}_{6}\left(\mathrm{~V}_{1}=\right.$ Flash power, $\mathrm{V}_{2}=$ Durga, $\mathrm{V}_{3}=$ BARI dheros $-2, \mathrm{~V}_{4}=$ Okra pornota, $\mathrm{V}_{5}=$ Dandy all green, $\mathrm{V}_{6}=$ Boishakhi). Post priming evaluation was done based on germination percentage, root-shoot length of seedlings, seedling height, and dry weight of seedlings, germination index and speed of germination at different days after sowing (5-15 DAS). Highest germination was observed in $V_{3}$ (88.00\%) and lowest was in $V_{5}$ (25.33\%). Root length was highest in $V_{3}$ and $V_{4}(8.77 \mathrm{~cm})$ and lowest was observed in $V_{2}(5.15 \mathrm{~cm})$. Shoot length of the seedlings was highest in $V_{3}(7.94 \mathrm{~cm})$ followed by $V_{1}$ (7.33). Shoot length of the seedlings was lowest in $V_{5}(5.12 \mathrm{~cm})$. Seedling height was highest in $V_{3}(16.71 \mathrm{~cm})$ which was followed by $V_{6}(16.26 \mathrm{~cm})$. The lowest seedling height was observed in $V_{1}(12.50 \mathrm{~cm})$. Dry weight of the seedlings was highest in $V_{3}(2.32 \mathrm{~g})$ which was followed in $V_{1}(2.26 \mathrm{~g})$. The lowest dry weight was observed in $V_{5}(1.99 \mathrm{~g})$. The variety $\mathrm{V}_{3}$ performed better in most of the evaluated parameters and suggested for commercial cultivation.

Keywords: Seed Priming; Okra,; Germination; Post germination

\subsection{Introduction}

Bangladesh is a country of sub tropical humid climate and suitable for growing all kinds of vegetable including okra. Okra (Abelmoschus esculentus L) is widely cultivated in all over the tropical regions and widely cultivated in subtropical regions of the world. It belongs to the family Malvaceae. It is originated in Africa, and grown in the Mediterranean region. It is a popular summer crop and growing round the year. It is a good source of vitamin A, B and C, and is also rich in protein, minerals and iodine. When dehisce, the black or brown white-eyed seeds are sometimes roasted and used as a substitute for coffee. The stem of the okra plant provides fiber which is used in paper industry.

Okra a nutritious vegetable might have poor seedling emergence and vigor in the field. Okra seeds do not germinate below $20^{\circ} \mathrm{C}$. The slow and uneven germination of okra seed is the main hurdle in the early spring planting [1]. The percentage of seed germination of okra is relatively low, due to the occurrence of hard seed in this plant [2]. The common ecological observation is that, after dispersal from the parent plant, the seeds fall onto the surface litter of the soil, where they may be able to survive for long periods either continuously or intermittently imbibed, therefore, with high water content.

Okra is a warm season crop, requiring ample moisture for germination. Seed priming is the pre-sowing treatment that involves the controlled hydration of seeds, sufficient to allow radical protrusion through the seed coat. It can also be explained as soaking seeds in water for a period of time and removing them such that germination does not continue once seeds are removed from the water. Seed priming is the pre-sowing treatment used as a technique to enhance seed germination, notably with respect to rate and uniformity, at a very wide range of favored and unfavored environmental conditions, thereby improving seedling stand and enabling of some better crop establishment [3]. Priming triggers the synthesis or activation of some enzymes that catalyze the mobilization of storage reserve in seed, while endosperm weakens by hydrolyses activates. Priming may increase resistance to abiotic stresses [4].

Farmers can prime their seeds if they know the maximum time length for soaking the seeds. In cultivation, the seeds are planted to a depth of 1-2 $\mathrm{cm}$. As reported by FAO, studies conducted in Zimbabwe, Pakistan and India reported that primed corn seeds emerged earlier, flowered sooner, required fewer cultivation and less weeding, produced grain faster and matured earlier than the same crops sown at the same time using dry seeds. Farmers reported better drought tolerance and higher yields using primed seeds with yield increase of 10-30\%. Less seeds per unit area were needed; for example, $19 \mathrm{~kg}$ per hectare of corn was needed instead of $25 \mathrm{~kg}$. Priming corn seed has spread to Thailand, Kenya, Uganda, Ethiopia, India and Tanzania. Corn grown from primed seeds generally emerges earlier and in greater numbers, grows more vigorously, flowers and matures earlier and often yields better than those from non-primed seeds.

Farmers in Bangladesh reported that primed crops emerged 2-3 days earlier than non-primed ones. Worley observed that a number of important factors, including seed quality could influence seed priming response. Therefore, the response to seed priming treatments might vary a mong seed lots because of differences in seed vigor. Hence the present research was undertaken to find out the effect of priming on germination and early seedling emergence in okra.

\subsection{Materials and Methods}

\subsection{Experimental conditions}

The Experiment was conducted at the Agricultural Field Laboratory of Sher-e Bangla Agricultural University, Sher-e-Bangla Nagar, Dhaka-1207, Bangladesh during the period from $15^{\text {th }}$ Oct to $30^{\text {th }}$ Nov 2016 (Robi season). The location of the experimental area was situated at $23^{\circ} 77^{\prime} \mathrm{N}$ latitude and $90^{\circ} 33^{\prime} \mathrm{E}$ longitude at an altitude of 9 meter above the sea level. Soil pH ranged from 6.0-6.6 and had organic matter 0.84\%. Experimental area was flat having available irrigation and drainage system and above flood level. Soil samples were collected from $0-15 \mathrm{~cm}$ depths. Glass petridishes ( $9 \mathrm{~cm}$ in diameter) were used in conducting the experiment. Filter paper was used in the petiridish as a matrix for seed germination. The diameter of filter paper was $9.0 \mathrm{~cm}$ having the whatman No.1. The experiment was conducted following Completely Randomized Design (CRD) with three replications. Seeds of Six local varieties of 0 kra $V_{1}=$ Flash power, $V_{2}=$ Durga, $V_{3}=$ BARI dheros $-2, V_{4}=0$ kra pornota, $V_{5}=$ Dandy all green, $V_{6}=$ Boishakhi selected for advancing the experiment. Therefore, the total number of petidishes was 38 (18 for treatment and 18 control). A number of 25 seeds were placed in each petridish. For seed priming; seed were soaked in the respective solutions water for $24 \mathrm{hrs}$. After three surface washings, the seeds were dried at $25^{\circ} \mathrm{C}$ for $24 \mathrm{hours}$ in the laboratory for close to original moisture level following standard procedure [5]. Untreated seed were used as control treatment. Emergence of radical was considered as germination [6]. Germination was observed daily and final data were planting after 5 days [7]. Data were recorded on germination percentage, seedling length, shoot length, root length, dry weight of seedling. All intercultural operations were done according to suggestion.

\subsection{Germination percentage}

Thirty seeds were randomly taken from each treatment and uniformly placed in sand. The rolled towels were kept in the seed germination and their 
constant temperature of $25 \pm 1^{\circ} \mathrm{C}, 94 \%$ relative humidity was maintained. The germination percentage was calculated based on the following equation [8] The germination percentage was calculated by the following formula

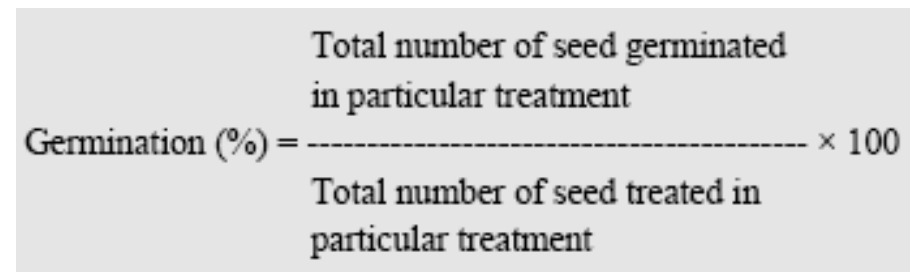

\subsection{Seedling length}

For the growth response, seedling length was allowed to continue grow. The seedling height (shoot + root length) were recorded after fifteen days of growth, the seedlings were up rooted and washed with distilled water to remove the foreign particles of sand. The shoot length was measured from the collar region to the point of attachment of cotyledons and the root length was measured from the collar region up the tip of root. The seedling height was expressed in centimeter.

\subsection{Root length}

After fifteen days of growth, the seedling were up rooted and washed with distill water to remove the foreign particle of sand. Root length of ten random selected seedlings from each replicate was measured in centimeter $(\mathrm{cm})$ from the base of hypocotyls to the tip of the longer root with the help of meter root. The average of each replication was calculated.

\subsection{Shoot length}

After fifteen days of growth, the seedling were uprooted and washed with distill water to remove the foreign particle of sand. Shoot length of ten random selected seedlings from each replicate was measured in centimeter $(\mathrm{cm})$ from the base of hypocotyls to the tip of the longer shoot with the help of meter root. The average of each replication was calculated.

\subsection{Dry weight of seedlings}

For dry weight of seedling, the ten randomly selected plant from each replicate were taken in paper bags and the placed in the open place under sunlight $26-30^{\circ} \mathrm{C}$ for 48 hours after that its placed in oven (Memmert-110, Schawabach) and dried at $70^{\circ} \mathrm{C}$ for 24 hours. The dry weight of both root and shoot were measured in a digital balance and average fresh and dry weight of seedling each replicate was taken.

\subsection{Experimental design and statistical analysis}

Data were collected as per CRD data format from different pot starting from the time. The data obtained for different characters were statisticaly analyzed to observe the significant difference among the treatment by using the MSTAT-C computer pakage program. The main value of all character was calculated and analyse of varience was performed. The significance of all difference among the treatments means was estimated by the least significant difference test (LSD) at 5\% level of probability [9].

\subsection{Results and discussion}

\subsection{Germination percentage (\%)}

Table 1. Evaluated parameters of six okra varieties

\begin{tabular}{|c|c|c|c|c|c|c|c|c|c|}
\hline \multirow[t]{2}{*}{ Variety } & \multirow{2}{*}{$\begin{array}{l}\text { Germination } \\
\text { (\%) }\end{array}$} & \multirow{2}{*}{$\begin{array}{l}\text { Root length of } \\
\text { seedling }(\mathrm{cm})\end{array}$} & \multirow{2}{*}{$\begin{array}{l}\text { Shoot length of } \\
\text { seedling }(\mathrm{cm})\end{array}$} & \multirow{2}{*}{$\begin{array}{l}\text { Seedling } \\
\text { length }(\mathrm{cm})\end{array}$} & \multirow{2}{*}{$\begin{array}{l}\text { Dry weight } \\
\text { of seedling } \\
\text { (g) }\end{array}$} & \multicolumn{2}{|c|}{ Shoot length(cm) } & \multirow[b]{2}{*}{11 DAS } & \multirow[b]{2}{*}{15 DAS } \\
\hline & & & & & & 5 DAS & 8 DAS & & \\
\hline$V_{1}$ & $77.33 \mathrm{~ns}$ & $8.50 \mathrm{~ns}$ & $7.33 \mathrm{~ns}$ & $15.83 \mathrm{ab}$ & $0.73 \mathrm{ab}$ & $2.24 \mathrm{a}$ & $3.00 \mathrm{a}$ & $3.54 \mathrm{ab}$ & $7.34 \mathrm{a}$ \\
\hline $\mathbf{V}_{2}$ & $78.66 \mathrm{~ns}$ & $8.58 \mathrm{~ns}$ & $6.94 \mathrm{~ns}$ & $15.52 \mathrm{ab}$ & $0.72 \mathrm{abc}$ & $2.38 \mathrm{a}$ & $2.55 \mathrm{ab}$ & $4.10 \mathrm{a}$ & $6.90 \mathrm{a}$ \\
\hline $\mathbf{V}_{3}$ & $88.00 \mathrm{~ns}$ & $8.77 \mathrm{~ns}$ & $7.94 \mathrm{~ns}$ & $16.71 \mathrm{a}$ & $0.77 \mathrm{a}$ & $2.42 \mathrm{a}$ & $3.19 \mathrm{a}$ & $4.23 \mathrm{a}$ & $7.94 \mathrm{ab}$ \\
\hline $\mathbf{V}_{4}$ & $68.00 \mathrm{~ns}$ & $8.77 \mathrm{~ns}$ & $7.20 \mathrm{~ns}$ & $15.30 \mathrm{ab}$ & $0.70 \mathrm{abc}$ & $2.06 \mathrm{a}$ & $2.30 \mathrm{ab}$ & $3.36 \mathrm{abc}$ & $7.00 \mathrm{ab}$ \\
\hline $\mathbf{V}_{5}$ & $25.33 \mathrm{~ns}$ & $8.31 \mathrm{~ns}$ & $5.12 \mathrm{~ns}$ & $13.45 \mathrm{~b}$ & $0.66 \mathrm{c}$ & $0.5 \mathrm{~b}$ & $1.59 \mathrm{~b}$ & $2.25 \mathrm{c}$ & $5.12 \mathrm{bc}$ \\
\hline$V_{6}$ & $70.66 \mathrm{~ns}$ & $8.65 \mathrm{~ns}$ & $5.64 \mathrm{~ns}$ & $16.26 \mathrm{a}$ & $0.68 \mathrm{bc}$ & $2.42 \mathrm{a}$ & $3.04 \mathrm{a}$ & $2.76 \mathrm{bc}$ & $5.61 \mathrm{c}$ \\
\hline LSD & - & - & - & 2.228 & 2.228 & 2.228 & 2.228 & 2.228 & 2.228 \\
\hline $\mathrm{CV}$ & - & - & - & 9.38 & 6.25 & 10.8 & 28.28 & 18.71 & 14.12 \\
\hline
\end{tabular}

* DAS=Days after sowing, data with same letter are not statistically significant in DMRT test.

Significant variation in the germination percentage was observed among the varieties of okra (Table 1). Highest germination percentage was in $V_{3}(88 \%)$ followed by $V_{2}(78.66 \%), V_{1}(77.33 \%)$ and $V_{6}(70.66)$. The lowest germination percentage ware found in $V_{5}(25.33)$ followed $V_{4}(68 \%)$. Therefore, $V_{3}$ may be potential variety and could be suggested for large scale production.

\subsection{Shoot length at 5 days after sowing (DAS)}

Significant variation was observed among the varieties for 5 days to first shoot length Okra (Table 1). Among the local varieties, highest 5 days to first shoot length was recorded in $V_{3}(2.42 \mathrm{~cm})$, followed by $V_{2}(2.38 \mathrm{~cm})$, Comparatively, Higher 5 days to fast shoot length $V_{1}(2.24 \mathrm{~cm})$ and $V_{6}(2.42 \mathrm{~cm})$. The lowest significant and identical days to fast shoot length were found in $V_{5}(0.5 \mathrm{~cm})$ and followed by $V_{4}(2.06 \mathrm{~cm})$. Higher shoot length in $V_{3}$ represents faster vegetative growth than other varieties.

\subsection{Shoot length at 8 days after sowing (DAS)}

Significant variation was observed among the varieties for 8 days to first shoot length Okra (Table 1). Among the local varieties, highest 8 days to first shoot length was recorded in $V_{1}(3 \mathrm{~cm})$, followed by $V_{6}(3.04 \mathrm{~cm})$, Comparatively, Higher 8 days to fast shoot length $V_{3}(3.41 \mathrm{~cm})$ and $V_{2}(3.00 \mathrm{~cm})$. The lowest significant and identical days to fast shoot length were found in $V_{5}(1.59 \mathrm{~cm})$ and followed by $V_{4}(2.30 \mathrm{~cm})$. 


\subsection{Shoot length at 11 days after sowing (DAS)}

Significant variation was observed among the varieties for 11 days to first shoot length Okra (Table 1). Among the varieties, highest 11 days to first shoot length was recorded in $V_{3}(4.23 \mathrm{~cm})$, followed by $V_{2}(4.10 \mathrm{~cm})$, Comparatively, Higher 11 days to fast shoot length $V_{1}(3.54 \mathrm{~cm})$ and $V_{4}(4.32 \mathrm{~cm})$. The lowest significant and identical days to fast shoot length were found in $V_{5}(2.25 \mathrm{~cm})$ and followed by $\mathrm{V}_{6}(2.76 \mathrm{~cm})$.

\subsection{Shoot length at 15 days after sowing (DAS)}

Significant variation was observed among the varieties for 15 days to first shoot length Okra (Table 1). Among the local varieties, highest 15 days to first shoot length was recorded in $V_{3}(7.94 \mathrm{~cm})$, followed by $V_{1}(7.34 \mathrm{~cm})$, Comparatively, Higher 15 days to fast shoot length $V_{4}(7.00 \mathrm{~cm})$ and $V_{2}(6.90 \mathrm{~cm})$. The lowest significant and identical days to fast shoot length was found in $V_{5}(5.12 \mathrm{~cm})$ and followed by $V_{6}(5.61 \mathrm{~cm})$. Higher shoot length in $V_{3}$ represents faster vegetative growth than other varieties.

\subsection{Root length of seedling (cm)}

Significant difference among the local varieties of okra was observed in root length. Higher root length was recorded in $V_{3}(8.77 \mathrm{~cm})$ and $V_{4}(8.77 \mathrm{~cm}), V_{6}$ $(8.65 \mathrm{~cm})$ while the lower value was observed in $\mathrm{V}_{5}(8.31 \mathrm{~cm}), \mathrm{V}_{1}(8.50 \mathrm{~cm}), \mathrm{V}_{2}(8.58 \mathrm{~cm})$ (Table 1). Root length range $8.31 \mathrm{~cm}$ to $8.77 \mathrm{~cm}$. Highest root length in $V_{3}$ represents faster vegetative growth than other varieties.

\subsection{Seedling length $(\mathrm{cm})$ at 15 DAS}

Significant different among the varieties of Okra were observed for plant Seedling length. Maximum seedling length was recorded in $V_{3}(16.71 \mathrm{~cm})$ and followed by $\mathrm{V}_{6}(16.26 \mathrm{~cm}), \mathrm{V}_{1}(15.83 \mathrm{~cm})$ while the minimum and statically $\mathrm{V}_{5}(13.45 \mathrm{~cm}), \mathrm{V}_{4}(15.30 \mathrm{~cm}), \mathrm{V}_{4}(15.52 \mathrm{~cm})$ (Table 1$)$. Soot length range 16.71 $\mathrm{cm}$ to $13.45 \mathrm{~cm}$. Highest seedling length in $V_{3}$ represents faster vegetative growth than other varieties

\subsection{Dry weight of seedling (g)}

Among the okra varieties, significant variation was also observed in seedling dry weight (Table 1$)$. Highest dry weight of seedling was recorded in $V_{3}(0.77 \mathrm{~g})$, followed by $V_{1}(0.73 \mathrm{~g})$ and $V_{2}(0.72 \mathrm{~g})$. While it was significantly lowest in $V_{5}(0.66 \mathrm{~g})$, followed by $\mathrm{V}_{6}(0.68 \mathrm{~g})$ and $\mathrm{V}_{4}(0.0137 \mathrm{~g})$. The overall weight ranged from $0.77 \mathrm{~g}$ to $0.66 \mathrm{~g}$. Highest dry weight in $\mathrm{V}_{3}$ represents faster vegetative growth than other varieties

\subsection{Conclusion}

To determine the effect of priming on germination and post germination early seedling stages, different parameters of six local okra varieties of Bangladesh were studied. The results revealed that hybrid BARI dheros-2 showed superiority among the tested six varieties as it showed highest seedling length (16.17 $\mathrm{cm})$, germination percentage $(88 \%)$, shoot length $(7.94 \mathrm{~cm})$, root length $(8.77 \mathrm{~cm})$ and dry weight $(0.77 \mathrm{~g})$. Conversely, $\left(V_{5}\right)$ "Dandy all green" variety showed the lowest value of seedling length $(13.45 \mathrm{~cm})$, germination percentage $(25.33 \%)$, shoot length $(5.12 \mathrm{~cm})$, root length $(8.31 \mathrm{~cm})$ and dry weight $(0.66 \mathrm{~g})$. So, BARI dheros-2 may be suggested for large scale production.

\subsection{References}

[1] V.K. Pandita, A. Anand, S. Nagarajan, R. Seth, and S.N. Sinha, "Solid matrix priming improves seed emergence and crop performance in okra", Plant Physiol., 38, Pp. 665-674, 2010

[2] V.P. Felipe, A.L. Antonio, and A.P. Francisco, "Improvement of okra (Abelmoschus esculentus L.) hardseedness by using microelements fertilizer", Hort. Bras., 28, Pp. 232-235, 2010.

[3] D. Job, I. Carpron, and C. Job, "Identification of specific protein makers and their use in seed priming technology", Seed Sci. Res., 7, Pp. 449-459, 2000.

[4] M. Farooq, S.M.A. Basra, H. Rehman, and B.A. Saleem, "Seed priming enhances the performance of late sown wheat (Triticum astivum L.) by improving chilling tolerance", J. Agron. Crop. Sci., 194, Pp. 55-60, 2008.

[5] M.M. Khan, M.J. Iqbal, and M.Abbas, "Effect of accelerated aging on viability, vigor and chromosomal damage in pea (Pisum sativum L.) seeds", Pakistan J. Agri. Sci., 40, Pp. 50-54, 2003.

[6] K. Chartzoulakis, and G. Klapaki, “Response of two greenhouse pepper hybrids to Nacl salinity during different growth stages”. Sci. Hortic., 86, Pp. 247260, 2000.

[7] ISTA [International Seed Testing Association] “International rules for seed testing”, Seed Sci. Techn., 21(Suppl.), Pp. 1-288. 1996.

[8] Anonymous, (International Seed Testing Association). “International rules for seed testing”, Seed Sci. Techn., 27 (Supplement), Pp. $333,1999$.

[9] K.A. Gomez and A.A. Gomez, “Statistical procedures for agricultural research”. 2nd Ed., Wiley, New York, Pp. 680, 1984. 